\title{
Photodegradation of Chlorbromuron, Atrazine, and Alachlor in Aqueous Systems under Solar Irradiation
}

\author{
Cristina Lizama Bahena and Susana Silva Martínez \\ Centro de Investigación en Ingeniería y Ciencias Aplicadas, Universidad Autónoma del Estado de Morelos, \\ Avenue Universidad 1001, Col. Chamilpa, Cuernavaca, Morelos 62210, Mexico \\ Received 16 April 2006; Accepted 5 June 2006
}

Homogeneous and heterogeneous aqueous systems of the herbicides of chlorbromuron, atrazine, and alachlor were irradiated with a nonexpensive solar irradiation using a photoreactor with recirculation. Photodegradation of these herbicides occurred in both aqueous systems; however the presence of $\mathrm{TiO}_{2}$ clearly accelerated the degradation of the three herbicides in comparison with direct photolysis. Degradation was followed by measuring the chemical oxygen demand (COD) as a function of reaction time for each aqueous system. Over $90 \%$ of COD abatement in the heterogeneous aqueous system was obtained in a short time period showing that mineralization of chlorbromuron, atrazine, and alachlor was achieved.

Copyright (C) 2006 C. L. Bahena and S. S. Martínez. This is an open access article distributed under the Creative Commons Attribution License, which permits unrestricted use, distribution, and reproduction in any medium, provided the original work is properly cited.

\section{INTRODUCTION}

The contamination of surface waters with herbicides results primarily from surface runoff from agricultural activities [1]. These chemicals are used to control insects, weeds, plant diseases, worms, and rodents. Atrazine and alachlor are widely used as a pre- and early post-emergent herbicide in maize and also for industrial weed control [2]. Thus, postapplication seasonal concentrations of different herbicides have been reported to exceed the maximum contaminant level permitted for surface waters [3]. It has been reported that atrazine is one of the most commonly detected herbicides in Europe and North America [4], with concentrations frequently reaching the grams per liter level for its properties of persistence and mobility [5]. Alachlor has been detected in ground water wells [6] despite its rapid microbial and photoinduced decomposition [7]. Herbicides urea type such as chlorbromuron, chloroxuron, chlorotoluron, diuron, and isoproturon are used to inhibit the photosynthesis process [8]. Herbicides are toxic to many organisms and have low solubility in water [9]. As a result, conventional biological remediation processes are not suitable to remove these substances from contaminated water and therefore alternative treatment methods are required.

There are several treatment processes available for the destruction or detoxification of hazardous organic wastes because of the growing restrictions placed on wastewater dis- charges and land disposal. Amongst these methods the advanced oxidation processes (AOPs) are the most promising alternative to treat herbicide wastes $[5,9-12]$ because they involve the generation of hydroxyl radicals $\left({ }^{\bullet} \mathrm{OH}\right)$ that are species nonselective and highly reactive oxidants [13]. The AOPs include processes based on hydrogen peroxide $\left(\mathrm{H}_{2} \mathrm{O}_{2}+\mathrm{UV}\right.$, fenton, photo-fenton, and fenton-like processes) $[14,15]$ photolysis [16], photocatalysis [16-19] and processes based on ozone $\left(\mathrm{O}_{3}, \mathrm{O}_{3}+\mathrm{UV}\right.$ and $\mathrm{O}_{3}+$ catalyst $)$ [20].

In this work the photodegradation (photolysis and photocatalysis methods) under nonexpensive solar irradiation are employed to decompose the herbicides: chlorbromuron, atrazine, and alachlor, in the presence and absence of $\mathrm{TiO}_{2}$ to show that it is possible to accomplish a complete oxidation of the herbicides in a relatively short time.

\section{METHODOLOGY}

\subsection{Chemicals}

All the chemicals were purchased from Sigma-Aldrich and used as received without further purification. $\mathrm{TiO}_{2}$, and $\mathrm{K}_{2} \mathrm{~S}_{2} \mathrm{O}_{8}$ were analytical grade. Chlorbromuron (3-(4Bromo-3-chlorophenyl)-1-methoxy-1-methylurea), atrazine (2-Chloro-4-(isopropylamino)-6-(ethylamino)-s-triazine), and alachlor (2-Chloro-2', 6'-diethyl-N-(methoxymethyl) 


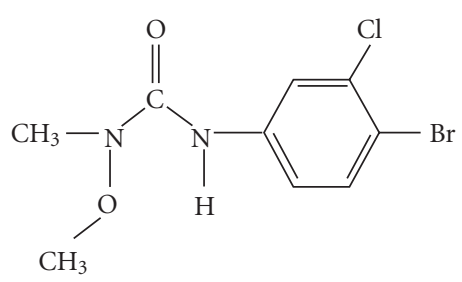<smiles>CCNc1nc(Cl)nc(NC(C)C)n1</smiles><smiles>CCc1cccc(CC)c1N(COC)C(=O)CCl</smiles>

Scheme 1: (a) Structural formula of chlorbromuron, (b) structural formula of atrazine, and (c) structural formula of alachlor.

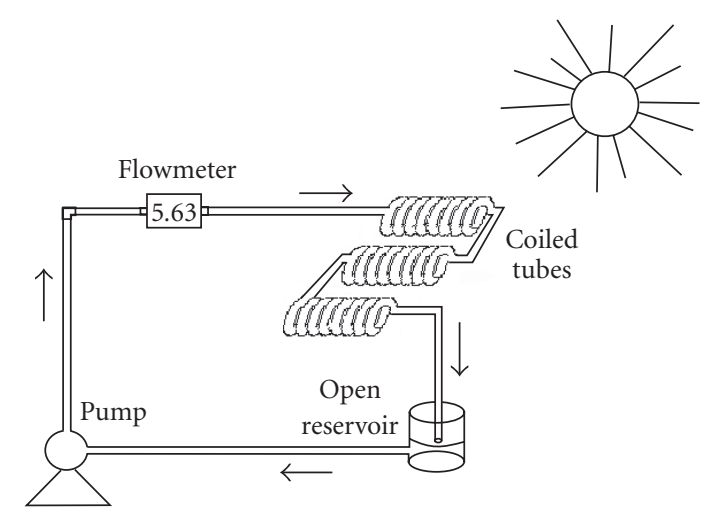

FIGURE 1: Experimental setup of the photoreactor with recirculation.

acetanilide) were HPLC grade (99.9\%). The structural formula of the herbicides is shown in Scheme 1. Distilled water was provided by BAXTER MEXCO.

\subsection{Procedures}

Stock solutions of chlorbromuron $\left(0.119 \mathrm{mmol} \mathrm{L}^{-1}\right)$, atrazine $\left(0.289 \mathrm{mmol} \mathrm{L}^{-1}\right)$, and alachlor $\left(0.267 \mathrm{mmol} \mathrm{L}^{-1}\right)$ were prepared with distilled water. The concentrations of chlorbromuron and atrazine were limited by their solubility. A series of photodegradation experiments for each herbicide were performed employing a photoreactor with recirculation. The photoreactor consisted of an open reservoir to allow the sample to be in contact with atmospheric air during circulation, a pump (5.64 gpm) and three-coiled tubes (25 cm long and $8 \mathrm{~mm}$ diameter) connected in series exposed horizontally to the solar irradiation, as shown in Figure 1. The experiments were performed from 12:00 to 14:00 hours (in the months of February and March) as this time period corresponds to the maximum incident solar light, which varies during the day and the season [21]. The total volume of the reactor was $250 \mathrm{ml}$; during sampling, care was taken to withdraw a volume of $<10 \%$ of the initial volume. Homogeneous and heterogeneous photodegradation was carried out under solar irradiation. Heterogeneous photodegradation took place with and without persulphate ion used as oxidant in the presence of $200 \mathrm{mg} \mathrm{L}^{-1} \mathrm{TiO}_{2}$ as catalyst [22]. Samples were withdrawn at different intervals of time to analyze the chemical oxygen demand (COD) using stan-

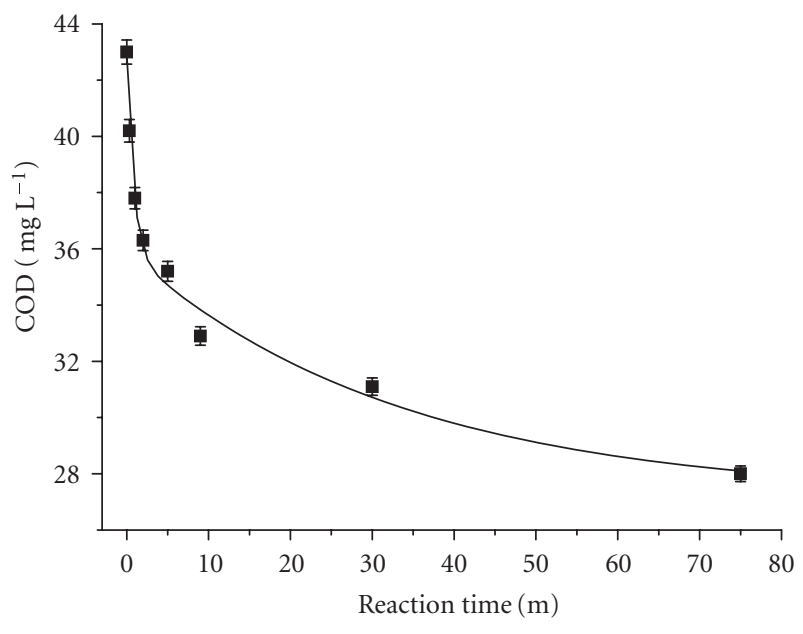

FIgURE 2: COD abatement of a solution of $0.119 \mathrm{mmol} \mathrm{L}^{1}$ chlorbromuron as a function of solar irradiation time. ( $\mathbf{\square})$ corresponds to the experimental data. (-) corresponds to a plot obtained from the best fit of the experimental data using the exponential decay second-order equation.

dard method and standard tubes [23] inside the range of $0-$ $150 \mathrm{mg} \mathrm{L}^{-1}$ and $0-40 \mathrm{mg} \mathrm{L}^{-1}$ COD. Samples were filtered as collected prior the analysis. The COD method involves a reaction between the organic matter and the dichromate ion in a $50 \%$ sulfuric acid solution.

\section{RESULTS AND DISCUSSION}

\subsection{Aqueous systems under dark conditions}

Negligible degradation of the three herbicides was observed in the absence of $\mathrm{TiO}_{2}$ or persulphate ion under dark conditions.

\subsection{Homogeneous aqueous systems under sun irradiation}

The photodegradation of the herbicides at concentration of $0.119 \mathrm{mmol} \mathrm{L}^{-1}$ chlorbromuron, $0.289 \mathrm{mmol} \mathrm{L}^{-1}$ atrazine and $0.267 \mathrm{mmol} \mathrm{L}^{-1}$ alachlor under solar irradiation is shown in Figures 2-4. These results revealed the occurrence of a rapid photolytic reaction, as there is a rapid reduction in COD in the first 2 minutes for the three organic compounds. 
TABLE 1: Showing the values for the constant parameters obtained from the best fit of the experimental COD data to an exponential decay second-order equation. $A_{1 \mathrm{HE}} / A_{1 \mathrm{HO}}$ is th ratio: $A_{1}$ from heterogeneous systems to $A_{1}$ from the homogeneous systems. $A_{2 \mathrm{HE}} / A_{2 \mathrm{HO}}$ is the ratio: $A_{2}$ from heterogeneous systems to $A_{2}$ from the homogeneous systems.

\begin{tabular}{|c|c|c|c|c|c|}
\hline \multirow{2}{*}{ Aqueous system } & \multicolumn{5}{|c|}{ Constant parameters } \\
\hline & $A_{1}$ & $A_{1 \mathrm{HE}} / A_{1 \mathrm{HO}}$ & $A_{2}$ & $A_{2 \mathrm{HE}} / A_{2 \mathrm{HO}}$ & $R^{2}$ \\
\hline Chlorbromuron + solar irradiation (homogeneous) & $6.930 \pm 1.061$ & \multirow{2}{*}{2.976} & $8.720 \pm 1.405$ & \multirow{2}{*}{2.562} & 0.9913 \\
\hline Chlorbromuron + solar irradiation $+\mathrm{TiO}_{2}$ (heterogeneous) & $20.623 \pm 1.941$ & & $22.343 \pm 1.487$ & & 0.9943 \\
\hline Atrazine + solar irradiation (homogeneous) & $19.134 \pm 0.679$ & \multirow{2}{*}{1.147} & $10.356 \pm 0.959$ & \multirow{2}{*}{2.793} & 0.9989 \\
\hline Atrazine + solar irradiation $+\mathrm{TiO}_{2}$ (heterogeneous) & $21.948 \pm 4.377$ & & $28.921 \pm 3.548$ & & 0.9844 \\
\hline Atrazine $+\mathrm{K}_{2} \mathrm{~S}_{2} \mathrm{O}_{8}+$ solar irradiation (homogeneous) & $3.229 \pm 8.62$ & \multirow{2}{*}{21.55} & $27.555 \pm 6.212$ & \multirow{2}{*}{1.667} & 0.9974 \\
\hline Atrazine $+\mathrm{K}_{2} \mathrm{~S}_{2} \mathrm{O}_{8}+$ solar irradiation $+\mathrm{TiO}_{2}$ (heterogeneous) & $69.585 \pm 2.054$ & & $45.935 \pm 5.291$ & & 0.9957 \\
\hline Alachlor + solar irradiation (homogeneous) & $25.139 \pm 2.149$ & \multirow{2}{*}{2.999} & $23.959 \pm 2.086$ & \multirow{2}{*}{2.315} & 0.9955 \\
\hline Alachlor + solar irradiation $+\mathrm{TiO}_{2}$ (heterogeneous) & $75.380 \pm 6.401$ & & $55.471 \pm 4.712$ & & 0.9929 \\
\hline
\end{tabular}

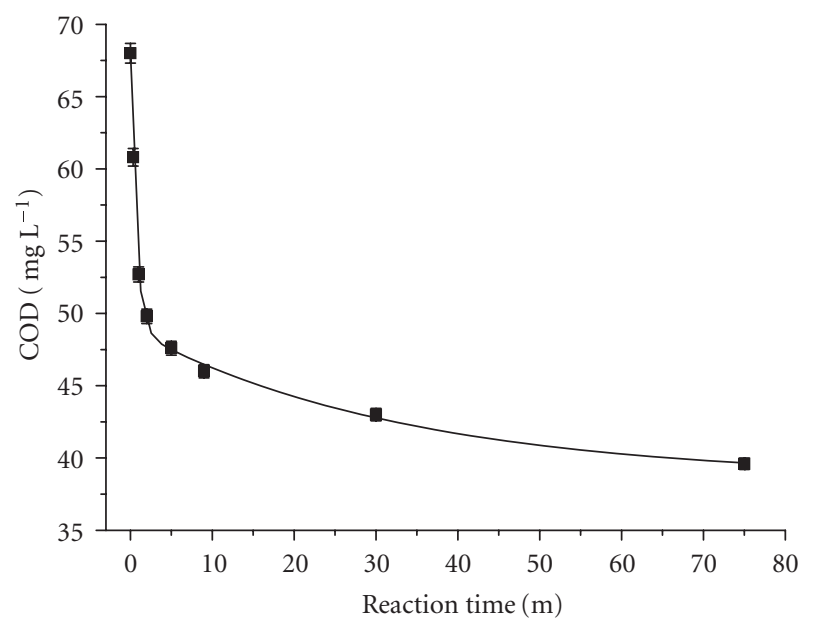

FIGURE 3: COD abatement of a solution $0.289 \mathrm{mmol} \mathrm{L}^{-1}$ atrazine as a function of solar irradiation time. ( $\mathbf{\square})$ corresponds to the experimental data. (-) corresponds to a plot obtained from the best fit of the experimental data using the exponential decay second-order equation.

However, no evidence of mineralization was found after 75 minutes of reaction because the COD was abated about $35 \%$, $41 \%$, and $35 \%$ of the initial COD value for chlorbromuron, atrazine, and alachlor, respectively. The statement of lack of mineralization is based on the observations reported by Seignez and coworkers [24]. These authors reported that a decrease of $20 \%$ of the initial COD value of an organic compound during degradation involves a primary structural chance of the initial organic molecule, while a COD abatement of $70 \%$ represents a complete mineralization as the end products are small molecules that can be biologically degraded.

The best fit of the experimental COD data, obtained during the photocatalytic degradation under solar irradiation of the three organic compounds, was found by fitting the data to an exponential decay second-order equation [25], shown below:

$$
y=y_{o}+A_{1} e^{\left(-x / t_{1}\right)}+A_{2} e^{\left(-x / t_{2}\right)}
$$

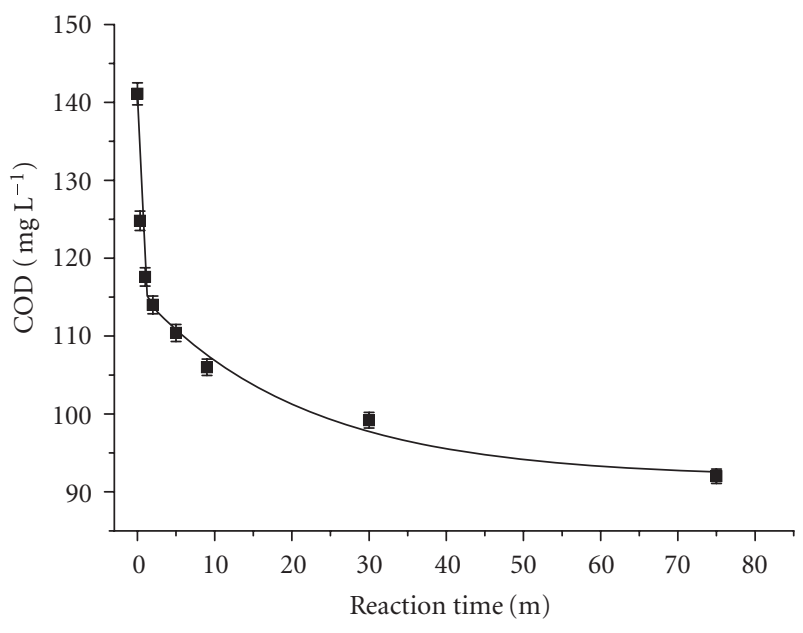

FIGURE 4: COD abatement of a solution of $0.267 \mathrm{mmol} \mathrm{L}^{-1}$ alachlor as a function of solar irradiation time. ( $\mathbf{\square})$ corresponds to the experimental data. (-) corresponds to a plot obtained from the best fit of the experimental data using the exponential decay second-order equation.

where $y$ corresponds to the experimental COD data obtained as a function of time, $x$ is the reaction time, and the rest of the parameters are constants obtained by fitting the data (shown in Table 1).

The mineralization of the three herbicides under solar irradiation is described by (2)-(4):

$$
\begin{aligned}
& \text { Chlorbromuron } \mathrm{C}_{9} \mathrm{H}_{10} \mathrm{BrClN}_{2} \mathrm{O}_{2}+\frac{25}{2} \mathrm{O}_{2} \\
& \qquad \stackrel{h v}{\longrightarrow} 9 \mathrm{CO}_{2}+\mathrm{HBr}+\mathrm{HCl}+2 \mathrm{HNO}_{3}+3 \mathrm{H}_{2} \mathrm{O}, \\
& \text { Atrazine } \mathrm{C}_{8} \mathrm{H}_{14} \mathrm{ClN}_{5}+\mathrm{H}_{2} \mathrm{O}+\frac{15}{2} \mathrm{O}_{2} \\
& \qquad \stackrel{h v}{\longrightarrow} 8 \mathrm{CO}_{2}+5 \mathrm{NH}_{3}+\mathrm{HCl}, \\
& \text { Alachlor } \mathrm{C}_{14} \mathrm{H}_{20} \mathrm{ClNO}_{2}+17 \mathrm{O}_{2} \\
& \qquad \stackrel{h v}{\longrightarrow} 14 \mathrm{CO}_{2}+\mathrm{NH}_{3}+\mathrm{HCl}+8 \mathrm{H}_{2} \mathrm{O}
\end{aligned}
$$

where $h v$ is the light energy, and the nitrogen atom can be transformed either to ammonia or nitrates. The calculation 
TABLE 2: Showing the theoretical and experimental COD values for the aqueous solutions of chlorbromuron, atrazine, and alachlor.

\begin{tabular}{lcccr}
\hline Herbicide name & Molecular weight $\left(\mathrm{g} \mathrm{mol}^{-1}\right)$ & Concentration $\left(\mathrm{mg} \mathrm{L}^{-1}\right)$ & $\mathrm{COD}_{\text {Theoretical }}\left(\mathrm{mg} \mathrm{L}^{-1}\right)$ & $\mathrm{COD}_{\text {Experimental }}\left(\mathrm{mg} \mathrm{L}^{-1}\right)$ \\
\hline Chlorbromuron & 293.50 & 35.0 & 47.7 & $44 \pm 2$ \\
Atrazine & 216.06 & 62.5 & 69.4 & $66 \pm 3$ \\
Alachlor & 269.77 & 72.1 & 145.2 & $141 \pm 7$ \\
\hline
\end{tabular}

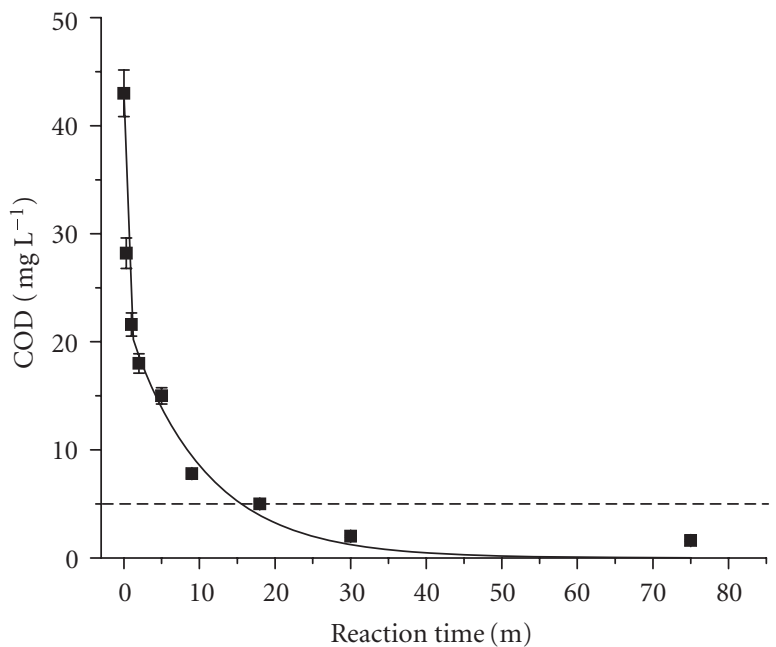

FIgURE 5: COD abatement of a solution $0.119 \mathrm{mmol} \mathrm{L}^{-1}$ chlorbromuron as a function of solar irradiation time in the presence of $\mathrm{TiO}_{2}$. The best fit (-) of the experimental data ( $\left.\mathbf{\square}\right)$ was for an exponential decay second-order equation. The dashed line represents the determination limit of COD method.

of the chemical oxygen demand [13] employing the stoichiometric coefficient of oxygen for each herbicide can be calculated according to (5):

$$
\mathrm{COD}\left(\text { in } \mathrm{mg} \mathrm{L}^{-1}\right)=\frac{\left(\mathrm{SC}-\mathrm{O}_{2}\right)\left(\mathrm{MW}-\mathrm{O}_{2}\right)(\mathrm{C}-\mathrm{H})}{\mathrm{MW}-\mathrm{H}},
$$

where $\mathrm{SC}-\mathrm{O}_{2}$ is the stoichiometric coefficient for oxygen in (2)-(4) for the respective herbicide, $\mathrm{MW}-\mathrm{O}_{2}$ is the molecular weight of oxygen (32), $\mathrm{C}-\mathrm{H}$ is the concentration of the herbicide in $\mathrm{mg} \mathrm{L}^{-1}$, and $\mathrm{MW}-\mathrm{H}$ is the molecular weight of each herbicide. Table 2 reports the theoretical and experimental COD values for each herbicide under study. These experimental COD values revealed that the proposed equations have good approximation for the mineralization of the herbicides.

\subsection{Heterogeneous aqueous systems under solar irradiation}

Figures 5-7 show COD abatement for chlorbromuron, atrazine, and alachlor under solar irradiation in the presence of $\mathrm{TiO}_{2}$, respectively. The degradation of chlorbromuron (Figure 5) and alachlor (Figure 7) was clearly faster than that under homogeneous irradiation. For instance, a removal of COD of $\sim 82 \%$ and $\sim 75 \%$ was achieved in a reaction time of

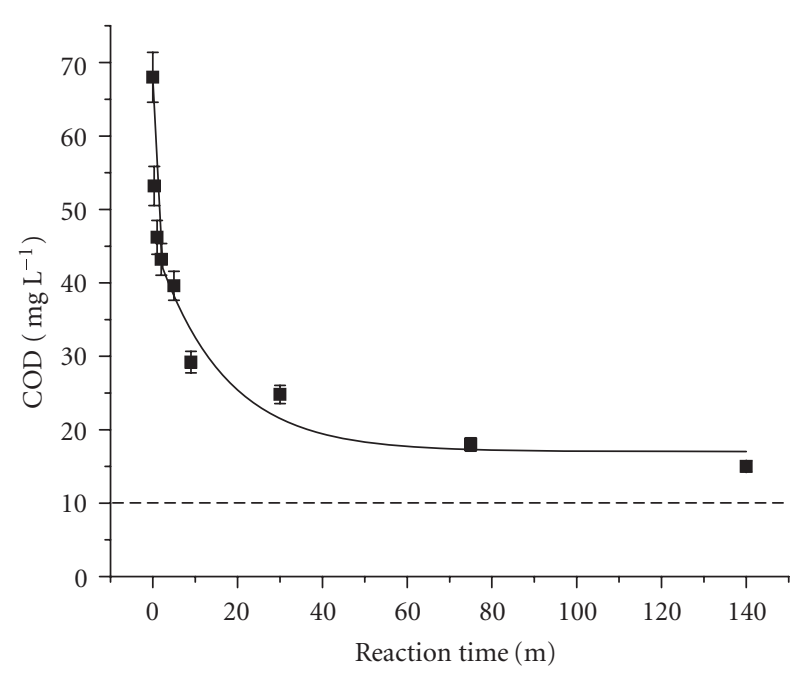

FIGURE 6: COD abatement of a solution $0.289 \mathrm{mmol} \mathrm{L}^{-1}$ atrazine as a function of solar irradiation time in the presence of $\mathrm{TiO}_{2}$. The best fit (-) of the experimental data ( $\boldsymbol{\square})$ was for an exponential decay second-order equation. The dashed line represents the determination limit of COD method.

9 minutes accomplishing a complete oxidation in less than 75 minutes of reaction. Regarding to the atrazine (Figure 6), the degradation also increased in the heterogeneous system compared to the homogeneous one; mineralization was achieved after 75 minutes of reaction with COD abatement of $\sim 74 \%$. The best fit of the experimental COD data was for an exponential decay second-order equation.

In order to further decrease the mineralization time for the atrazine, persulphate ion $\left(\mathrm{K}_{2} \mathrm{~S}_{2} \mathrm{O}_{8}, 10 \mathrm{mM}\right)$ was added as oxidant to the heterogeneous photodegradation of atrazine under solar irradiation. This oxidant enhances mineralization of organic compounds during the degradation process compared to $\mathrm{TiO}_{2}$ alone. The reactions where $\mathrm{S}_{2} \mathrm{O}_{8}^{2-}$ ions are involved are expressed by (6)-(10):

$$
\begin{gathered}
\mathrm{S}_{2} \mathrm{O}_{8}^{2-}+\mathrm{e}_{\mathrm{CB}}^{-} \longrightarrow \mathrm{SO}_{4}^{2-}+\mathrm{SO}_{4}^{--}, \\
\mathrm{SO}_{4}^{\cdot-}+\mathrm{e}_{\mathrm{CB}}^{-} \longrightarrow \mathrm{SO}_{4}^{2-}, \\
\mathrm{SO}_{4}^{\cdot-}+\mathrm{H}_{2} \mathrm{O} \longrightarrow \mathrm{SO}_{4}^{2-}+{ }^{\bullet} \mathrm{OH}+\mathrm{H}^{+},
\end{gathered}
$$

$\mathrm{SO}_{4}^{--}+$organic compound $\longrightarrow \mathrm{SO}_{4}^{2-}+$ oxidised species,

$$
\mathrm{S}_{2} \mathrm{O}_{8}^{2-}+h v \longrightarrow 2 \mathrm{SO}_{4}^{\bullet-},
$$

where $\mathrm{e}_{\mathrm{CB}}^{-}$is the electron generated in the $\mathrm{TiO}_{2}$ conduction band [26-28]. Photolysis of $\mathrm{S}_{2} \mathrm{O}_{8}^{2-}$ also produces two 


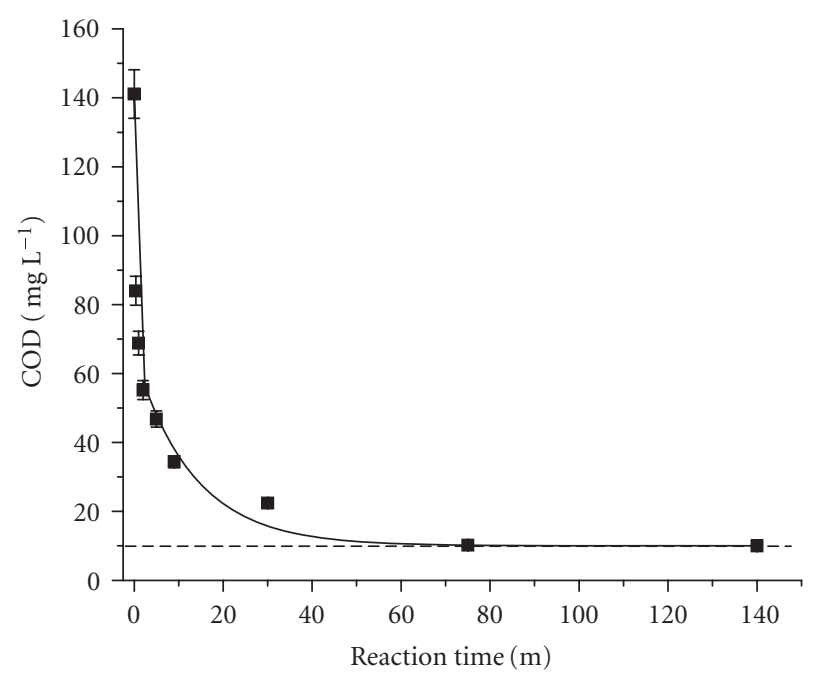

FIgURE 7: COD abatement of a solution of $0.267 \mathrm{mmol} \mathrm{L}^{-1}$ alachlor as a function of solar irradiation time in the presence of $\mathrm{TiO}_{2}$. The best fit (-) of the experimental data ( $\boldsymbol{\square})$ was for an exponential decay second-order equation. The dashed line represents the determination limit of COD method.

sulphate radical anions (10), which are also strongly oxidizing species $\left(\mathrm{E}^{\circ}=2.6 \mathrm{~V}\right)[28]$, generating a very reactive ion $\mathrm{SO}_{4}^{-\bullet}$, able to attack organic compounds by abstraction of a hydrogen atom or addition on unsaturated molecules.

Figure 8 shows the photodegradation of atrazine with persulphate ion $\left(\mathrm{S}_{2} \mathrm{O}_{8}^{2-}\right)$ in the presence $(\boldsymbol{\square})$ and absence $(\boldsymbol{\Lambda})$ of $\mathrm{TiO}_{2}$ under solar irradiation. This figure clearly shows that the degradation of atrazine with persulphate ion is a slow chemical reaction and reports a decrease of $\sim 20 \%$ of COD after 20 minutes of reaction resulting in a primary change of the original structure of the atrazine; therefore, the persulphate ion needs to be catalyzed. While the heterogeneous system in the presence of persulphate ion exhibits a rapid photochemical reaction. It is worth to mention that $\mathrm{S}_{2} \mathrm{O}_{8}^{2-}$ reacts with dichromate in the COD test, and therefore increases the apparent organic content in the sample [13], as shown for the initial COD value in this figure. Nevertheless, a COD removal of $\sim 70 \%$ is achieved at 45 minutes and a $~ 91 \%$ at 140 minutes of reaction for the heterogeneous system ( $\mathbf{\square})$. These results show that the mineralization of atrazine in presence of an oxidant during the heterogeneous degradation under solar irradiation can be achieved in a shorter time than that obtained without the persulphate ion.

Table 1 reports a comparison of the constant parameters obtained from the best fit of the experimental COD data obtained from the homogeneous and heterogeneous photodegradation of the three herbicides. It can be observed from the value of the ratios for the heterogeneous/homogeneous constant parameters for chlorbromuron and alachlor that the heterogeneous photodegradation was increased more than two times compared to the homogeneous photolysis. Regarding to the atrazine, the ratios showed a little increase in the degradation of atrazine; however, the heterogeneous photolysis in the presence of both

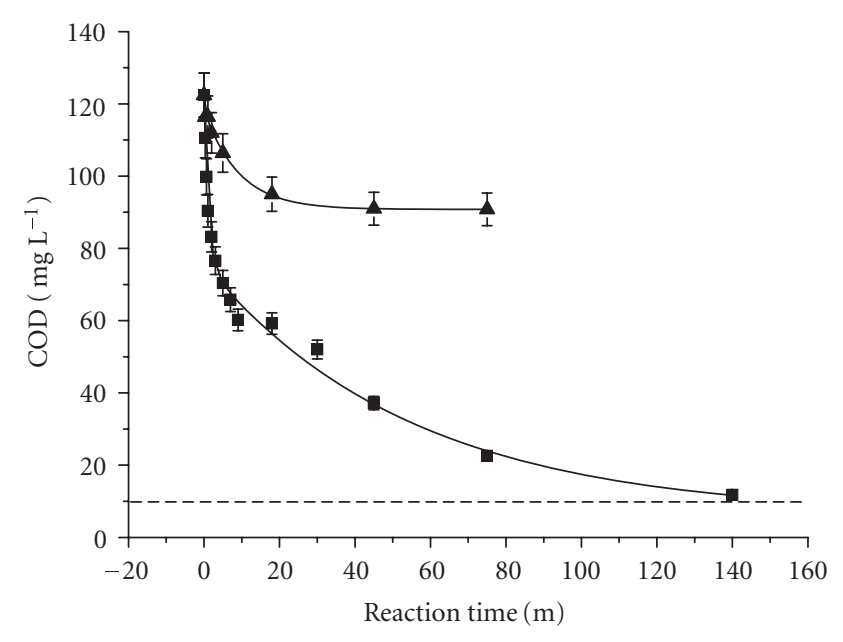

FIGURE 8: COD abatement of a solution of $0.289 \mathrm{mmol} \mathrm{L}^{-1}$ atrazine versus reaction time under solar irradiation: $(\mathbf{\square})$ with $10 \mathrm{mmol} \mathrm{L} \mathrm{L}^{-1}$ $\mathrm{K} 2 \mathrm{~S} 2 \mathrm{O}$ and $200 \mathrm{mg} \mathrm{L}^{-1} \mathrm{TiO}_{2}$; (ム) with $10 \mathrm{mmol} \mathrm{L}^{-1} \mathrm{~K} 2 \mathrm{~S} 2 \mathrm{O} 8$. The best fit (-) of the experimental data was for an exponential decay second-order equation. The dashed line represents the determination limit of COD method.

persulphate ion and $\mathrm{TiO}_{2}$ was increased for more than 21 times than that obtained with persulphate ion as shown by the ratio with $A_{1}$ parameter.

\section{CONCLUSIONS}

This work has shown that the heterogeneous photocatalysis is a good method for the degradation of chlorbromuron, atrazine, and alachlor in aqueous systems under non-expensive solar irradiation. Although the homogeneous aqueous systems that employed the sole sun irradiation produced a primary structural chance of the original molecule of each herbicide, mineralization was not achieved. However, photocatalysis in the presence of $\mathrm{TiO}_{2}$ not only produced a primary structural change of the original molecule of each herbicide, but also produced the mineralization of the three organic compounds in a short time period by the employment of sun irradiation.

The photocatalytic process under nonexpensive solar irradiation represents an alternative to degrade several organic compounds that are biologically slowly degraded. The photocatalytic process could also be followed by a biological process once the COD for the organic contaminants has been decreased to $\sim 70 \%$ of the initial COD value, because at this final COD the original molecule of the compound has been transformed to small molecules that any biological process can further decompose to achieve a complete oxidation of such compound.

\section{ACKNOWLEDGMENTS}

This work was financially supported by the Programa de Mejoramiento del Profesorado (PROMEP) of the Secretaría de Educación Pública (SEP). We thank CONACYT for the Grant given to C. Lizama Bahena to support her Doctor studies. 


\section{REFERENCES}

[1] G. Tchobanoglous, F. Burton, and H. D. Stensel, Wastewater Engineering: Treatment and Reuse, Metcalf \& Eddy, McGraw Hill, New York, NY, USA, 2003.

[2] A. Seiler, P. Brenneisen, and D. H. Green, "Benefits and risks of plant protection products possibilities of protecting drinking water: case atrazine," Water Supply, vol. 10, no. 2, pp. 31-42, 1992.

[3] H. Nelson and R. Jones, "Potential regulatory problems associated with atrazine, cyanazine, and alachlor in surface water source drinking water," Weed Technology, vol. 8, no. 4, pp. 852861, 1994.

[4] W. E. Pereira and C. E. Rostad, "Occurrence, distributions, and transport of herbicides and their degradation products in the lower Mississippi river and its tributaries," Environmental Science and Technology, vol. 24, no. 9, pp. 1400-1406, 1990.

[5] K. H. Chan and W. Chu, "Environmental: atrazine removal by catalytic oxidation processes with or without UV irradiation: part II: an analysis of the reaction mechanisms using LC/ESItandem mass spectrometry," Applied Catalysis B: Environmental, vol. 58, no. 3-4, pp. 165-174, 2005.

[6] R. F. C. Chester, G. V. Simsiman, J. Levy, B. J. Alhajjar, R. N. Fathulla, and J. M. Harkin, "Environmental fate of alachlor and metolachlor," Reviews of Environmental Contamination and Toxicology, vol. 110, pp. 1-74, 1989.

[7] J. Tiedje and M. L. Hagedorn, "Degradation of alachlor by a soil fungus, Chaetomium globosum," Journal of Agricultural and Food Chemistry, vol. 23, no. 1, pp. 77-81, 1975.

[8] CICOPLAFEST (1998). Catálogo Oficial de Plaguicidas. Secretaría de Agricultura y Recursos Hidráulicos. México, D.F.

[9] E. M. Rodríguez, P. M. Álvarez, F. J. Rivas, and F. J. Beltrán, "Wet peroxide degradation of atrazine," Chemosphere, vol. 54, no. 1, pp. 71-78, 2004.

[10] D. G. Wayment and D. J. Casadonte, Jr, "Frequency effect on the sonochemical remediation of alachlor," Ultrasonics Sonochemistry, vol. 9, no. 5, pp. 251-257, 2002.

[11] K. H. Chan and W. Chu, "Atrazine removal by catalytic oxidation processes with or without UV irradiation: part I quantification and rate enhancement via kinetic study," Applied Catalysis B: Environmental, vol. 58, no. 3-4, pp. 157-163, 2005.

[12] I. Rezić, A. J. M. Horvat, S. Babić, and M. Kaštelan-Macan, "Determination of pesticides in honey by ultrasonic solvent extraction and thin-layer chromatography," Ultrasonics Sonochemistry, vol. 12, no. 6, pp. 477-481, 2005.

[13] Metcalf \& Eddy, Wastewater Engineering. Treatment and Reuse, Revised by G. Tchobanoglous, F. Burton, H. D. Stensel, McGraw Hill, New York, NY, USA, 2003.

[14] Q. Wang and A. T. Lemley, "Oxidation of diazinon by anodic Fenton treatment," Water Research, vol. 36, no. 13, pp. 32373244, 2002.

[15] J. J. Pignatello, "Dark and photoassisted $\mathrm{Fe}^{3+}$-catalyzed degradation of chlorophenoxy herbicides by hydrogen peroxide," Environmental Science and Technology, vol. 26, no. 5, pp. 944951, 1992.

[16] E. T. Oppelt, "Handbook on Advanced Photochemical Oxidation Processes," EPA/625/R-98/004, December 1998.

[17] J.-M. Herrmann, "Heterogeneous photocatalysis: fundamentals and applications to the removal of various types of aqueous pollutants," Catalysis Today, vol. 53, no. 1, pp. 115-129, 1999.
[18] A. M. Braun and E. Oliveros, "How to evaluate photochemical methods for water treatment," Water Science and Technology, vol. 35, no. 4, pp. 17-23, 1997.

[19] S. Malato, J. Blanco, A. Vidal, and C. Richter, "Photocatalysis with solar energy at a pilot-plant scale: an overview," Applied Catalysis B: Environmental, vol. 37, no. 1, pp. 1-15, 2002.

[20] F. J. Beltrán, J. M. Encinar, and J. F. González, "Industrial wastewater advanced oxidation. Part 2. Ozone combined with hydrogen peroxide or UV radiation," Water Research, vol. 31, no. 10, pp. 2415-2428, 1997.

[21] M. M. Higarashi and W. F. Jardim, "Remediation of pesticide contaminated soil using $\mathrm{TiO}_{2}$ mediated by solar light," Catalysis Today, vol. 76, no. 2-4, pp. 201-207, 2002.

[22] S. Malato, J. Blanco, B. Milow, M. I. Maldonado, and C. Richter, "Tratamiento de plaguicidas de la agricultura intensiva almeriense mediante la tecnología de detoxificación solar," Ambiente Ecológico, vol. 85, 2002, www.ambiente-ecologico .com.

[23] Water Analysis Handbook, Hach Company, Loveland, Colo, USA, 1992.

[24] C. Seignez, C. Pulgarin, P. Peringer, C. Comninellis, and E. Plattner, "Degradation of industrial organic pollutants. Electrochemical and biological treatment and combined treatment," Swiss Chem, vol. 14, no. 1, pp. 25-30, 1992.

[25] Origin Data Analysis and Technical Graphics Software, (1999), Microcal Software, Verson 6.

[26] O. Zahraa, L. Sauvanaud, G. Hamard, and M. Bouchy, "Kinetics of atrazine degradation by photocatalytic process in aqueous solution," International Journal of Photoenergy, vol. 5, no. 2, pp. 87-93, 2003.

[27] B. Neppolian, S. R. Kanel, H. C. Choi, M. V. Shankar, B. Arabindoo, and V. Murugesan, "Photocatalytic degradation of reactive yellow 17 dye in aqueous solution in the presence of $\mathrm{TiO} 2$ with cement binder," International Journal of Photoenergy, vol. 5, no. 2, pp. 45-49, 2003.

[28] M. H. Pérez, G. Peñuela, M. I. Maldonado, et al., "Degradation of pesticides in water using solar advanced oxidation processes," Applied Catalysis B: Environmental, vol. 64, pp. 272$281,2006$. 


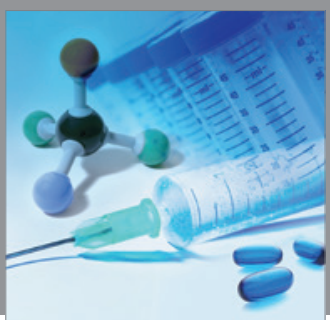

International Journal of

Medicinal Chemistry

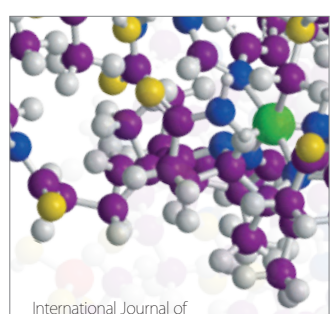

Carbohydrate Chemistry

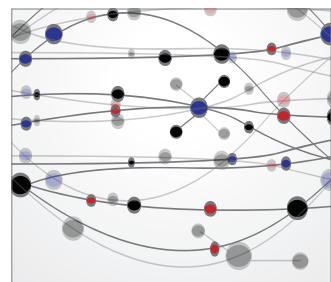

The Scientific World Journal
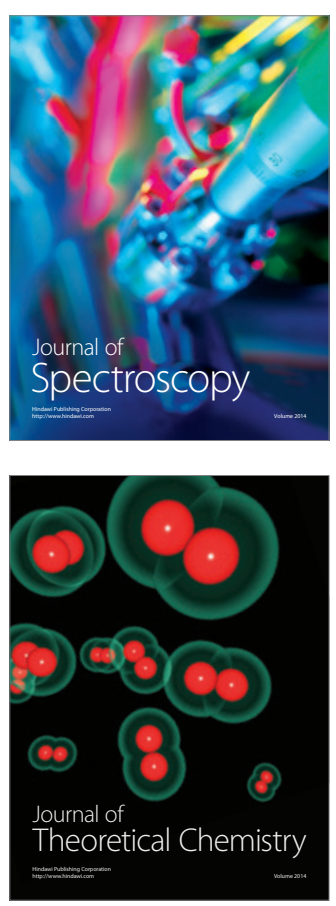
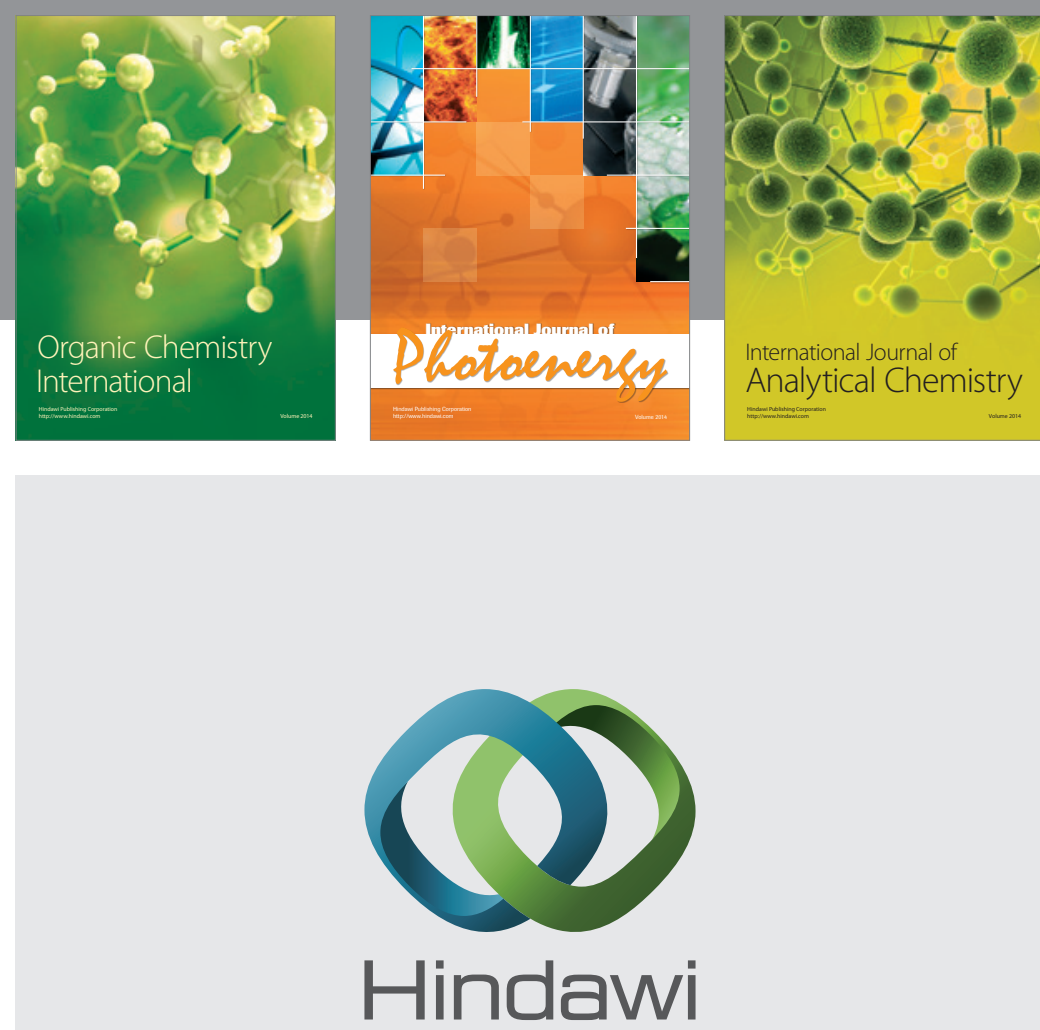

Submit your manuscripts at

http://www.hindawi.com
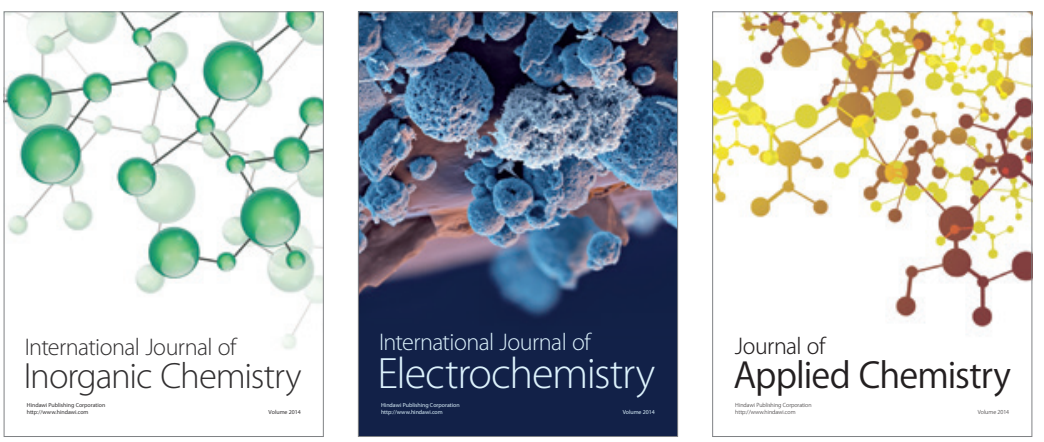

Journal of

Applied Chemistry
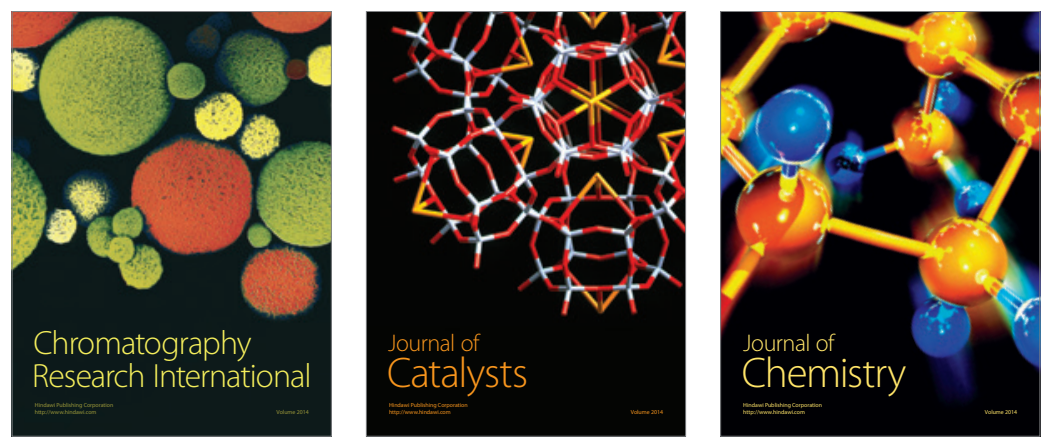
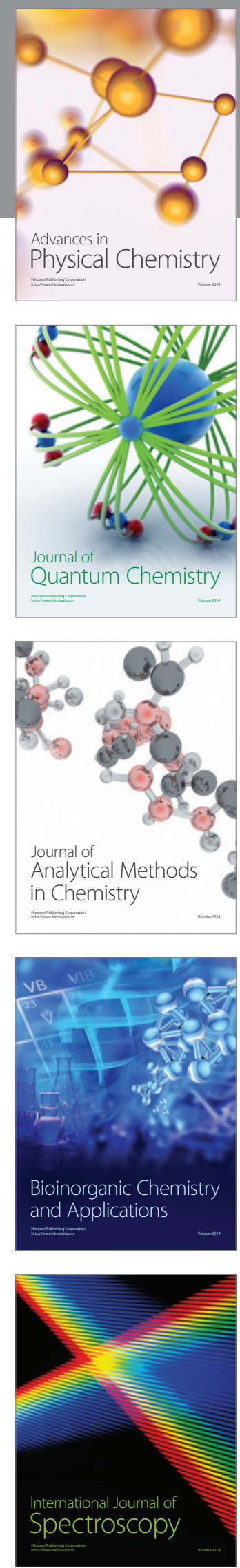